\title{
Cross-Border Portfolio Investment and Financial Markets Development in the Asia and Pacific Region
}

\author{
Sayuri Shirai ${ }^{1,2}$ \& Eric Alexander Sugandi ${ }^{1,3}$ \\ ${ }^{1}$ Asian Development Bank Institute, Tokyo, Japan \\ ${ }^{2}$ Faculty of Policy Management, Keio University, Tokyo, Japan \\ ${ }^{3}$ Graduate School of Asia Pacific Studies, Waseda University, Tokyo, Japan \\ Correspondence: Eric Alexander Sugandi, Asian Development Bank Institute, Kasumigaseki Building 8F, 3-2-5, \\ Kasumigaseki, Chiyoda-ku, Tokyo 100-6008, Japan.
}

Received: February 25, 2019

Accepted: April 8, $2019 \quad$ Online Published: April 17, 2019

doi:10.5539/ibr.v12n5p14

URL: https://doi.org/10.5539/ibr.v12n5p14

\begin{abstract}
This study examines cross-border portfolio investment in the Asia and Pacific region throughout 2001-2017, where rapid increases in investment have taken place particularly after the 2008-2009 global financial crisis. Cross-border portfolio investment in this region has the following characteristics. First, equity has been a dominant source of foreign liabilities notwithstanding efforts to develop bond markets in the region. Second, debt securities have remained dominant foreign assets held by the region. Third, the region's assets and liabilities linkages have remained overwhelmingly strengthened against the United States and the European Union. However, the region has also witnessed greater intra-regional financial integration, centering at China with growing linkages with Hong Kong and Singapore. Fourth, Japan as a country with the largest abundant domestic capital in the region has remained predominantly exposed to the United States and the European Union. Within the region, nonetheless, debt securities issued by Australia have increasingly attracted Japan's capital.
\end{abstract}

Keywords: portfolio investment, financial markets development, Asia and Pacific

\section{JEL Classification: F36, G15}

\section{Introduction}

The Asia and Pacific region has deepened economic integration through trade and foreign direct investment (FDI) since the early 1990s. The momentum has been stronger since the early 2000s, thanks to the participation of China in the World Trade Organization. According to the Asian Development Bank (ADB), the ratio of intra-regional trade in "Asia" has risen from about 53\% in 2001 to $58 \%$ in 2016, while the share of intra-regional FDI rose from $47 \%$ to $50 \%$ over the same period (ADB 2018). ADB's definition of "Asia" includes forty-eight Asia and Pacific countries.

In contrast, the degree of intra-regional financial market integration within the Asia and Pacific region has remained small. Among Asia and Pacific economies, Hong Kong has been a major financier of cross-border capital to the securities issued by the region, followed by Japan, and Singapore. Among these economies, Hong Kong has acted as a major equity financier to China. Singapore has been an active equity investor to China, Japan, Korea, and other economies in the ASEAN (Association of Southeast Asian Nations). Meanwhile, Japan's exposure to the region has remained largely in the form of debt securities issued by Australia. Limited capital inflows to debt securities issued by emerging Asia may reflect the early stages of bond market developments (such as lack of liquidity, wide range of maturity, and depth).

The global financial crisis of 2008-2009 and the subsequent unconventional monetary easing policy adopted by advanced economies in the United States (US), the European Union (EU), and Japan have affected the movements of cross-border portfolio capital flows in the Asia and Pacific region. In the initial phase of the crisis, the region faced an outflow of portfolio investment. In the later phase of the crisis (when advanced economies have eased monetary policies), the region has witnessed a new wave of cross-border portfolio inflows from investors in the US and the EU in search of higher yields in the region.

This paper explores the characteristics of the movements of cross-board portfolio assets and liabilities in the Asia 
and Pacific region over the period 2001-2017, by dividing into the three periods: 2001-2007 (before the global financial crisis), 2008-2009 (during the crisis), and 2010-2017 (after the crisis). When referring to the Asia and Pacific region, this paper focuses on ten economies: Japan, Hong Kong, China, Korea, Indonesia, Malaysia, the Philippines, Singapore, Thailand, and Australia. Of these, ASEAN-5 covers Indonesia, Malaysia, the Philippines, Singapore, and Thailand. This paper pays greater attention to Japan, China, Hong Kong, Singapore, and Australia due to the presence of large international financial centers. According to the Global Financial Center Index published by Z/Yen (2019) released in March 2019, four financial centers in Asia and Pacific are in the top ten list of the world's leading financial centers: Hong Kong $\left(3^{\text {rd }}\right)$, Singapore $\left(4^{\text {th }}\right)$, Shanghai $\left(5^{\text {th }}\right)$, Tokyo $\left(6^{\text {th }}\right)$, and Beijing $\left(9^{\text {th }}\right)$.

Aside from business papers and articles published by financial sector research institutions primarily targeting global investors, few academic papers have been written on cross-border portfolio investment in the region. A study by Caporale et al. (2019) using cointegration analysis find the existence of cointegration between the ASEAN-5 and the US but almost none between the former and China, except between Indonesia and China in the case of the financial sector. Using the structural VAR analysis Shu et al. $(2015,2016)$ finds the growing influence of Chinese equity and currency movements in the region, although China remains a negligible player in the bond market. A study by Hattari and Rajan (2011) using the fixed effect panel data analysis finds that both cross-border portfolio investment and direct investment are positively affected by the economic sizes of the source and host countries of investment, but negatively affected by the distance between them.

This paper is different from these previous papers as it provides more non-technical insights on the distinctive features of cross-border portfolio investment in the three periods, and how such investment flows affect financial markets development and integration in the region. This paper pays closer attention to bilateral portfolio inflows within the Asia and Pacific economies and between these economies with the EU and the US. Nonetheless, this paper also conducted random effect pooled data analysis to identify factors that affect cross-border portfolio investment inflows to the region as a supplement to the main analysis.

The analysis in this paper is mainly based on cross-border portfolio assets and liabilities data from the Coordinated Portfolio Investment Survey (CPIS) compiled by the International Monetary Fund (IMF). The data excludes portfolio assets managed under foreign reserves. The CPIS data are obtained from the holdings of portfolio investment classified by the investor (creditor) country/economy so that the IMF provides derived liabilities data for all countries/economies from the investor information. Caution is necessary as investor country/economy does not necessarily indicate the residency of the investors; rather, it may indicate the country/region of foreign custodians or other intermediaries. Another caution is that data reflect both the effects of price changes (including exchange rates) and investment shifts.

The paper is organized into five sections. Section 2 overviews financial markets development in the Asia and Pacific region since the 1997-1998 Asian economic crisis. Section 3 explores differences in features of cross-border portfolio investment in the region before, during, and after the 2008-2009 global financial crisis. Section 4 discusses the features of the region's portfolio investment assets and liabilities based on the type instrument. Section 5 concludes.

\section{Financial Markets Development Since the Asian Economic Crisis of 1997-1998}

The 1997-1998 Asian economic crisis was attributable to domestic firms' high dependence on domestic bank loans that borrowed heavily from abroad, as well as the absence of proper supervisory and prudential regulations on domestic commercial banks amid crony relations among banks, firms, and governments. Having learned from the crisis, the following five consensus views emerged among authorities in the Asia and Pacific region.

First, the region should develop domestic bond markets to reduce firms' excessive dependence on the banking system (Yoshitomi \& Shirai 2001). Developing local currency-denominated corporate bond markets would be essential to minimize "double mismatches" borne by commercial banks, as were seen before the 1997-1998 crisis. Double mismatches here refer to the currency mismatch and maturity mismatch. A currency mismatch arose from commercial banks borrowing in foreign currencies from abroad and lending into the private sector in local currencies. A maturity mismatch was associated with commercial banks' borrowing in short-term from foreign banks and lending into the private sector in longer-term loans. Developing corporate bond markets enables the economies to minimize double mismatches since firms would issue local currency-denominated longer-term bonds.

Second, a well-developed government bond market would enable central banks to conduct a more modernized, effective monetary policy - by shifting from the practice of heavy intervention in the foreign exchange markets to the practice of open market operations using government bonds and other bonds as collateral. Well-developed 
government and private bond markets would contribute to developing the repurchase agreement (Repo) markets and diverse asset-backed securities (ABS) markets, thereby contributing to the interbank market activities. Developing longer-term debt securities markets would be essential for fostering the pension funds and insurance industries to match their long-term liabilities.

Third, the authorities in the region should make efforts to develop viable domestic bond markets through collective efforts, since it would take time to develop such markets independently. The bond markets were underdeveloped in emerging economies as there were only a small number of large, reputable private firms that would enable the issuing of a large number of corporate bonds regularly. Demand for longer-term bonds was also relatively limited due to the early stage of financial asset accumulation from pension funds and insurance industries. Supervisory agencies, legal infrastructures, and corporate governance codes remained underdeveloped. Therefore, simultaneous development in the corporate bond markets in the region could attract more sustainable capital inflows from various types of investors from abroad.

Fourth, equity markets should be developed further to promote more diversified capital inflows to the region. The number of listed firms was limited in emerging Asia. Liquidity in equity markets was also limited due to the concentrated ownership of shares, and lack of adequate transparency and investor protection. Concentrated ownership was associated with risks, primarily through the possible extraction of undue private benefits for the controlling owner (OECD 2017). Thus, firms wishing to lower leverage by reducing short-term and foreign debt would benefit from equity market development. Household and institutional investors (such as pension funds and insurance firms) might also be able to diversify financial risk and raise returns.

Fifth, the region should utilize their accumulated large savings more efficiently to realize sustainable economic growth, for example by increasing infrastructure and productive business investment - rather than strengthening capital flow relationships from advanced economies/regions such as the US and the EU. As for advanced Asian economies with relatively developed capital and financial markets like Japan, abundant domestic savings should be invested more heavily in the Asia and Pacific region to promote intra-regional financial integration.

In line with the afore-mentioned consensus views, the authorities in the Asia and Pacific region have made deliberate efforts to increase the issues of government bonds with a wide range of maturity, aiming to establish effective benchmark yield curves essential for pricing corporate bonds. Some economies - such as Hong Kong and Singapore, whose fiscal balances have been positive most of the time - also made efforts to issue government bonds. Meanwhile, Korea standardized the coupon rates and maturities of government bonds under the Fungible Issue System in 2000 to increase liquidity in the government bond market and stabilize the reference interest rate (BlackRock 2017). This initiative was followed by a conversion offer system where off-the-run government bonds were exchanged for on-the-run bonds.

In addition to these country-level initiatives, the governments and central banks in the Asia and Pacific region have also made joint efforts to develop their capital markets. For example, the governments in the ASEAN plus three (China, Japan, and Korea) introduced the Asian Bond Market Initiative (ABMI) in 2002 to investigate concrete measures to promote domestic bond markets. Furthermore, the Executives' Meeting of East Asia-Pacific Central Banks (EMEAP) launched the Asian Bond Fund (ABF1) to develop US dollar-denominated sovereign and quasi-sovereign bond markets under the management of the Bank for International Settlements (BIS) in 2003. The EMEAP then introduced ABF2 to develop local currency-denominated bond markets managed by private sector fund managers and administered by the BIS in 2004. As local currency-denominated bonds were developed, the EMEAP decided to close the ABF1 and transferred the funds registered in $\mathrm{ABF} 1$ to ABF2 in 2016.

Reflecting these initiatives, the local currency-denominated bond markets have grown in the Asia and Pacific region over time (Table 1). The 2008-2009 global financial crisis encouraged the governments in the region to implement fiscal stimulus measures to cope with the recession, thereby increasing government bond issues. While Japan has the largest government bond market in the region, the pace of growth in other bond markets has been greater than that of Japan.

Meanwhile, the rapid growth in the corporate bond market in the region has been attributed to the global financial crisis triggered in the US and the EU. The crisis reduced cross-border banking capital inflows from banks in these economies to the region. Consequently, some banks in the region became more cautious in extending loans domestically. Some large firms in the region, therefore, increased the issuance of securities, which invited capital inflows from advanced economies to the region in search for higher yields. 
Table 1. Size of Local Currency Bond Markets in Asia and Pacific Economies (Unit: US\$ Billions, \%)

\begin{tabular}{lrrrrrr}
\hline & \multicolumn{2}{c}{ December 2007} & \multicolumn{2}{c}{ December 2017 } & \multicolumn{2}{c}{$\%$ Change } \\
\cline { 2 - 7 } & Government & Corporate & Government & Corporate & Government & Corporate \\
\hline Japan & 6,874 & 773 & 9,523 & 692 & 39 & -10 \\
China & 1,532 & 157 & 6,327 & 2,413 & 313 & 1,441 \\
Hong Kong & 18 & 80 & 148 & 96 & 745 & 19 \\
Korea & 498 & 529 & 827 & 1,193 & 66 & 125 \\
Indonesia & 77 & 8 & 156 & 29 & 102 & 244 \\
Malaysia & 95 & 70 & 166 & 152 & 75 & 118 \\
Philippines & 55 & 3 & 89 & 20 & 63 & 473 \\
Singapore & 68 & 54 & 166 & 106 & 144 & 98 \\
Thailand & 111 & 28 & 252 & 95 & & 126 \\
\hline
\end{tabular}

Source: Asian Bond Monitor March 2018, ADB.

Some economies have lengthened the maturity of government bonds between 2007 and 2017, suggesting that a wide range of government bonds have been issued and thus the longer-end of the yield curve has been formed. For example, the share of government bonds with maturity more than 10 years has increased in Thailand, Singapore, the Philippines, Malaysia, Korea and Japan (Figure 1). Meanwhile, Thailand, the Philippines, Malaysia, Korea, and China have reduced the share of government bonds with maturity of 1-3 years over the same period.

(1) December 2007

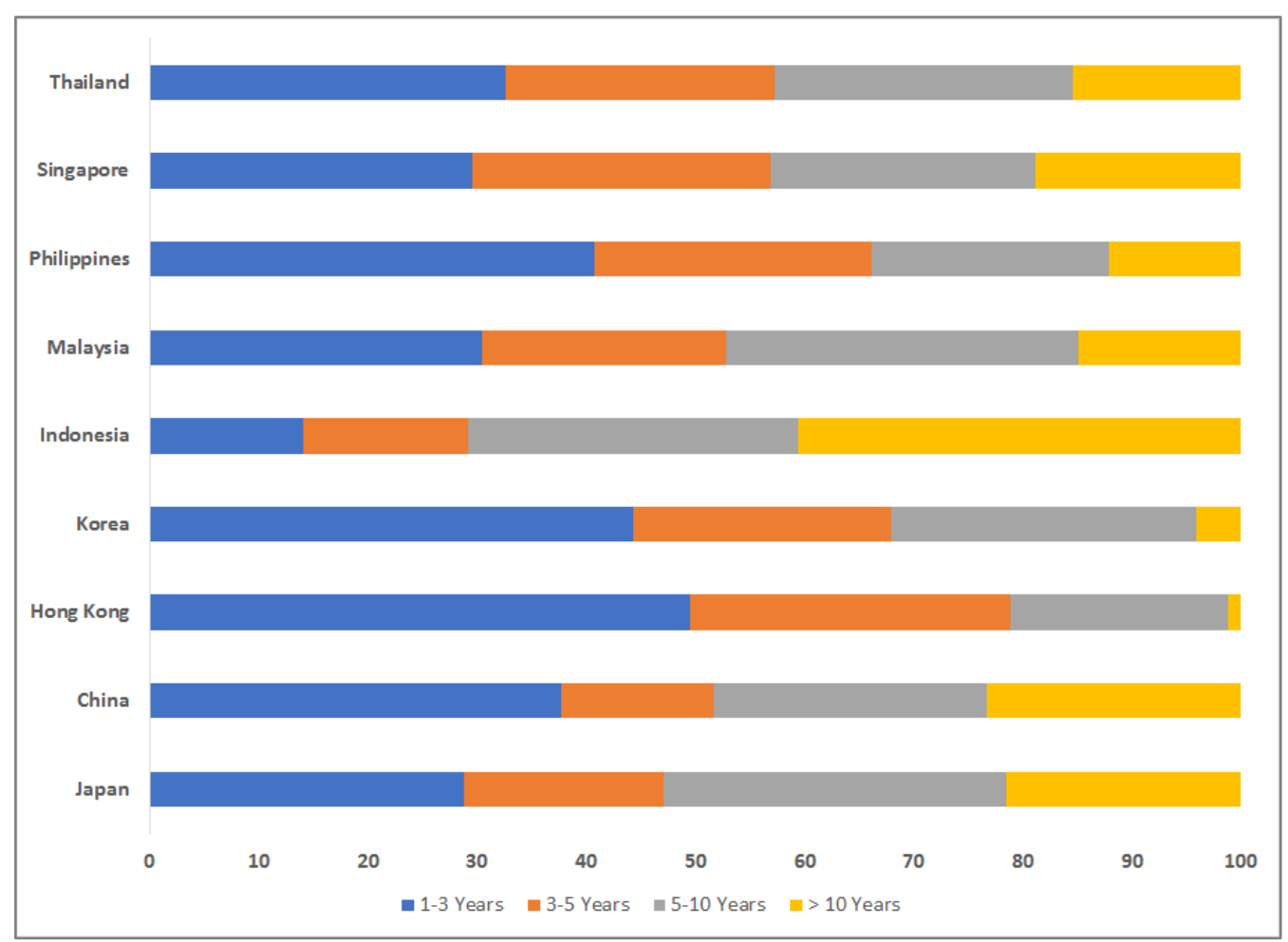


(2) December 2017

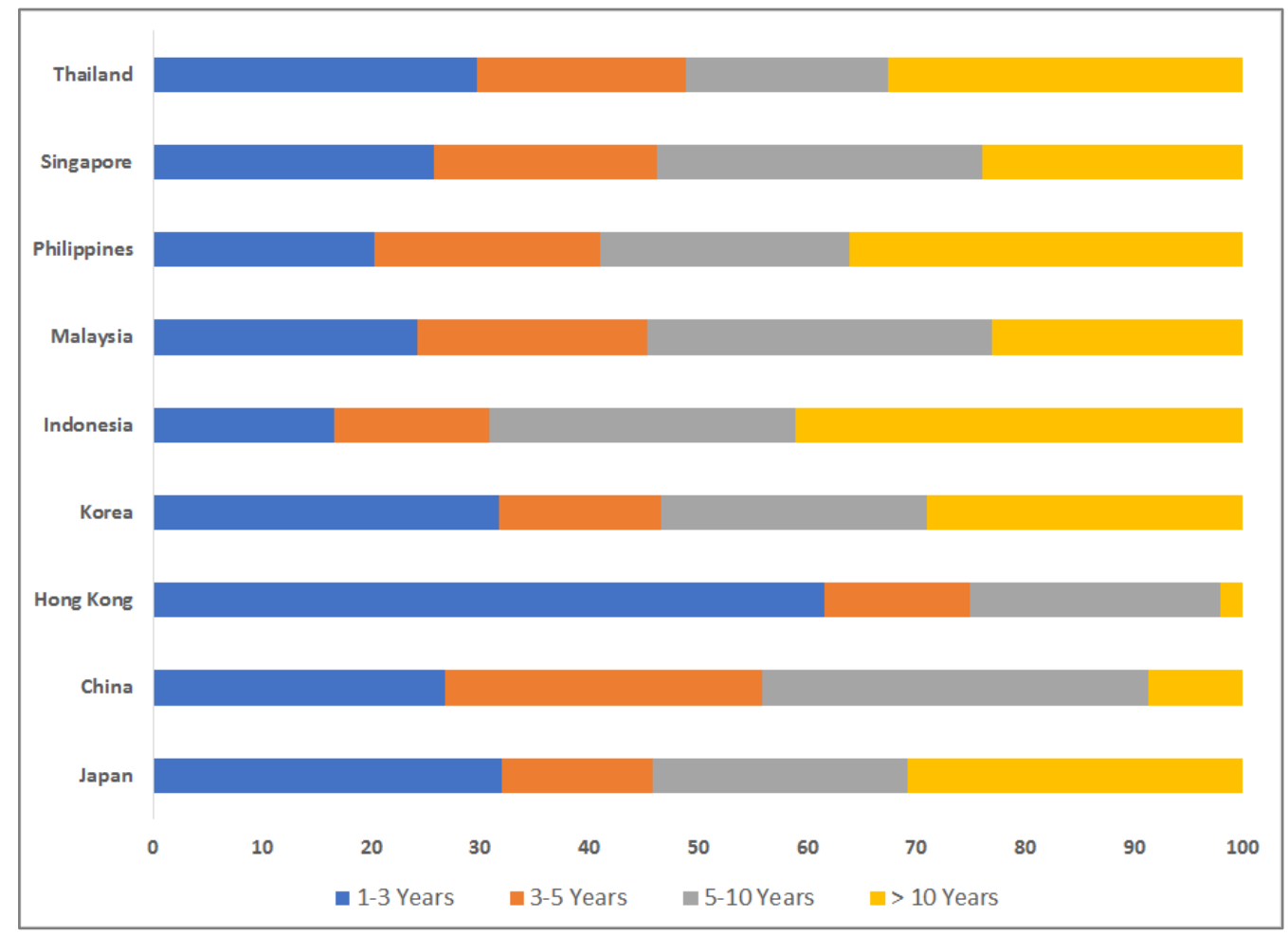

Figure 1. Maturity Profiles of Government Bonds (Unit: \% of Total)

Source: Asian Bonds Online, ADB.

The investor base for government bonds has widened in some economies. Table 2 shows that the share of contractual savings institutions (including pension funds and life insurance firms) has risen in Japan, Korea, Indonesia, and Thailand over the past ten years. In the case of China, banks' share has remained dominant, accounting for more than $60 \%$ throughout the same period. The rising share of contractual savings institutions reflects an improvement in per capita income and progress made on wealth accumulation managed by insurance companies and pension funds. Households are increasingly able to diversify their assets away from liquid and short-term bank deposits to wider options of investment instruments, as pension funds and insurance firms continue to develop.

Table 2. Investors' Profiles of Government Bonds in Asia and Pacific Economies (Unit: \% of Total)

\begin{tabular}{llrrrrr}
\hline \multirow{3}{*}{ Japan } & Central Bank & Government & Banks & Contractual Savings Institutions & Others \\
& December 2007 & 9 & 12 & 37 & 20 & 21 \\
\multirow{5}{*}{ China } & December 2010 & 9 & 11 & 41 & 21 & 18 \\
& December 2017 & 41 & 5 & 17 & 22 & 16 \\
& December 2007 & 0 & 0 & 63 & 7 & 30 \\
& December 2010 & 0 & 0 & 72 & 9 & 20 \\
& December 2017 & 0 & 0 & 66 & 3 & 30 \\
& December 2007 & 3 & 26 & 22 & 24 & 24 \\
& December 2010 & 3 & 26 & 19 & 27 & 25 \\
& December 2017 & 2 & 20 & 16 & 36 & 26 \\
& December 2007 & 3 & - & 56 & 14 & 26 \\
& December 2010 & 3 & - & 34 & 18 & 45 \\
& December 2017 & 7 & - & 23 & 17 & 53 \\
& December 2007 & - & - & - & - & - \\
& December 2010 & 1 & 0 & 34 & 40 & 24 \\
& December 2017 & 1 & 0 & 32 & 38 & 29 \\
\hline
\end{tabular}




\begin{tabular}{lllllll}
\hline Thailand & December 2007 & 5 & 3 & 17 & 39 & 36 \\
& December 2010 & 2 & 2 & 23 & 43 & 30 \\
& December 2017 & 4 & 1 & 17 & 52 & 25 \\
\hline
\end{tabular}

Source: Asian Bonds Online, ADB.

Most of the government and corporate bonds issued by the Asia and Pacific economies are denominated in local currencies. According to the ADB Bonds Online data, China had the largest outstanding amount of government and corporate bonds issued denominated in foreign currencies (about US\$659 billion, as of end-September 2017), but it accounted for only 7\% of the total outstanding amount of issued bonds in 2017 (Table 3). Similarly, Japan had the second largest outstanding amount of bonds denominated in foreign currencies (US\$403 billion), but it accounted for only $4 \%$ of the total as of end-December 2017. In contrast, Hong Kong more actively issued bonds denominated in foreign currencies (US\$167 billion), accounting for $41 \%$ of the total as of end-September 2017. The issuances of bonds denominated in foreign currencies were predominantly conducted by firms in China and Japan. These foreign-currency denominated bonds are largely issued in US dollars; small amounts are issued in euro and Japanese yen. China has been the largest issuer of foreign currency-denominated bonds.

Foreign investors have become major investors in the securities issued by the Asia and Pacific economies. According to the ADB Bonds Online data, foreign investors hold about $40 \%$ of outstanding government bonds issued in Indonesia, 29\% in Malaysia, and 16\% in Thailand as of end-December 2017. Government bonds issued by Indonesia, Malaysia, Korea, the Philippines, and Thailand are included in various emerging market local currency sovereign bond indices - such as the Bloomberg Emerging Market Local Currency Sovereign Bond Index. Indonesian and Malaysian bonds are preferred among foreign investors due to attractive yields. While steadily growing, foreign ownership of government bonds issued by China accounts for only slightly above 3.5\% due to capital controls.

Table 3. The Size of Local and Foreign Currency Bond Markets in Asia and Pacific Economies, 2017*

(Unit: US\$ Billions, \% of Foreign Currency Bonds to Total)

\begin{tabular}{|c|c|c|c|c|c|c|c|}
\hline & \multicolumn{3}{|c|}{ Local Currency } & \multicolumn{3}{|c|}{ Foreign Currency } & \multirow{2}{*}{$\begin{array}{l}\% \text { of } \\
\text { Foreign } \\
\text { Currency } \\
\text { Bonds to } \\
\text { Total }\end{array}$} \\
\hline & $\begin{array}{l}\text { Government } \\
\text { Bonds }\end{array}$ & $\begin{array}{l}\text { Corporate } \\
\text { Bonds }\end{array}$ & Total & $\begin{array}{l}\text { Government } \\
\text { Bonds }\end{array}$ & $\begin{array}{l}\text { Corporate } \\
\text { Bonds }\end{array}$ & Total & \\
\hline Japan & 9,523 & 692 & 10,215 & 62 & 341 & 403 & 4 \\
\hline China & 6,315 & 2,413 & 8,728 & 58 & 601 & 659 & 7 \\
\hline Hong Kong & 148 & 96 & 244 & 0 & 167 & 167 & 41 \\
\hline Korea & 827 & 1,193 & 2,020 & 30 & 123 & 153 & 7 \\
\hline Indonesia & 156 & 29 & 185 & 70 & 35 & 105 & 36 \\
\hline Malaysia & 166 & 152 & 318 & 10 & 31 & 41 & 11 \\
\hline Philippines & 89 & 20 & 109 & 29 & 10 & 39 & 26 \\
\hline Singapore & 166 & 106 & 272 & 66 & 0 & 66 & 19 \\
\hline Thailand & 252 & 95 & 347 & 2 & 14 & 16 & 4 \\
\hline
\end{tabular}

*Note: All data refer to end-December 2017, except for data on foreign currency bonds of China and Hong Kong that refer to end-September 2017.

Source: Asian Bonds Online, ADB.

Government bonds have remained dominant in most of the Asia and Pacific economies. The exception is Korea, where the size of the corporate bond market exceeds the size of the government bond market (Table 3). This is attributable to the Korean government's various initiatives to develop the corporate bond market since the early 1970s, including: (i) introduction of the system of bond guarantee in 1972; (ii) elimination of restrictions on investment in domestic bonds by foreign investors after the Asian economic crisis; (iii) introduction of asset-backed securities in 1998; (iv) provision of support on the corporate bond market in the early 2000s (when Daewoo Group collapsed in 2000 and accounting scandals involving SK Group erupted in 2003) with the adoption of the Korea Development Bank Prompt Underwriting Scheme; and (v) introduction of high-yield bond funds and qualified institutional buyers' market (BlackRock 2017). In Asia, most corporate bonds are high-rated (very few junk bonds) and shorter term than government bonds.

Although the bond markets have been growing in the Asia and Pacific economies, liquidity problems have 
remained due to relatively low trading volumes in both the government and corporate bond markets. Meanwhile, the region's equity markets have grown more rapidly than bond markets. Table 4 exhibits the rapid growth in the market capitalization of domestic stock exchanges in the region.

Table 4. Domestic Market Capitalization in Asia and Pacific Economies (Unit: US\$ Million, \%)

\begin{tabular}{llrrr}
\hline & & \multicolumn{1}{c}{2003} & 2017 & $\%$ Change \\
\hline Japan & Japan Exchange Group Inc. & $2,953,098$ & $6,222,825$ & 111 \\
China & Shanghai Stock Exchange & 360,106 & $5,089,631$ & 1,313 \\
& Shenzhen Stock Exchange & 152,872 & $3,621,636$ & 2,269 \\
Hong Kong & Hong Kong Exchanges and Clearing & 714,597 & $4,350,515$ & 509 \\
Korea & Korea Exchange & 298,248 & $1,771,796$ & 494 \\
Indonesia & Indonesia Stock Exchange & 54,659 & 520,687 & 853 \\
Malaysia & Bursa Malaysia & 160,814 & 455,772 & 183 \\
Philippines & Philippine Stock Exchange & 23,176 & 290,401 & 1,153 \\
Singapore & Singapore Exchange & 148,503 & 787,255 & 430 \\
Thailand & The Stock Exchange of Thailand & 119,017 & 548,795 & 361 \\
Australia & Australian Securities Exchange & 585,530 & $1,508,463$ & 158 \\
\hline
\end{tabular}

Source: World Federation of Exchange.

\section{Cross-Border Portfolio Assets and Liabilities in the Asia and Pacific Region Before, During, and After the 2008 - 2009 Global Financial Crisis}

This section discusses the distinctive features of cross-border portfolio investment in the Asia and Pacific region before, during, and after the global financial crisis. Figure 2 shows the annual cross-border portfolio investment assets of the Asia and Pacific economies in the world from 2001 to 2017, while Figure 3 displays the portfolio investment liabilities of the Asia and Pacific economies to the world. The "world" here comprises both the Asia and Pacific region and economies outside the region (i.e., "the rest of the world").

Japan has been the biggest cross-border portfolio investor in the Asia and Pacific region, but the share of its assets to total cross-border portfolio assets in the region has gradually declined, because Hong Kong, Singapore, and Australia have increased their overseas investment (Figure 2). Japan has also been the biggest recipient of portfolio investment in the Asia and Pacific, but its share to total cross-border liabilities in the region has gradually fallen, as world's investment to other countries in the region (particularly to Australia and China) have increased (Figure 3).

The actual amounts of cross-border portfolio investment assets and liabilities of Asia and Pacific economies are reported in Appendix 1, Appendix 2, and Appendix 3. The average amount of cross-border portfolio positions and their distributions by investing and receiving countries are exhibited in Appendix 1 for the before the crisis period (2001-2007), in Appendix 2 for the crisis period (2008-2009), and in Appendix 3 for the post-crisis period (2010-2017). The analysis below will focus on the five economies with major global financial centers: (1) Japan, (2) China, (3) Hong Kong, (4) Singapore, and (5) Australia. China's time-series analysis is limited due to the lack of data on its cross-border assets for the pre-crisis and the crisis periods. 


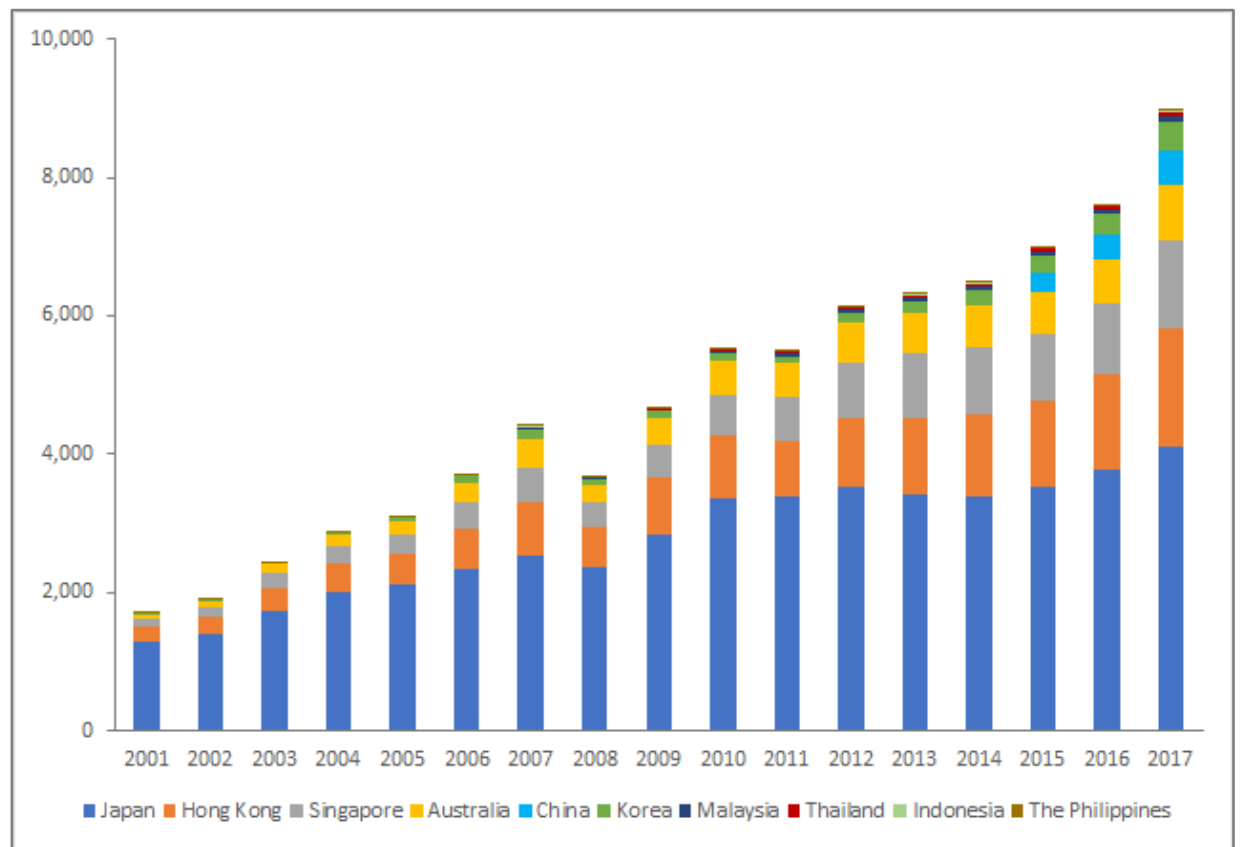

Figure 2. Cross-border Portfolio Investment Assets in the Asia and Pacific Region by Economy (US\$ Billion) Source: Coordinated Portfolio Investment Survey (CPIS), IMF

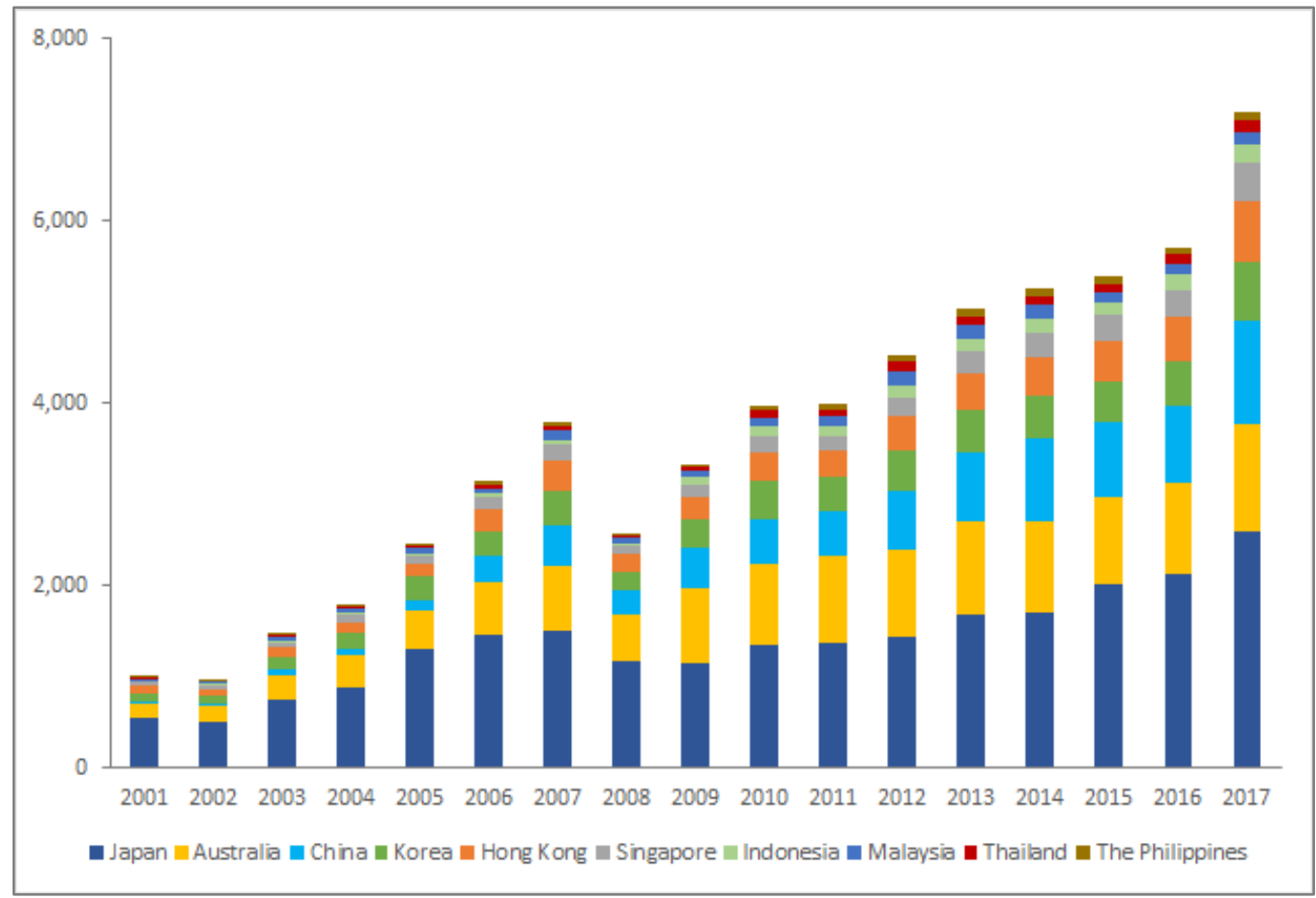

Figure 3. Cross-border Portfolio Investment Liabilities in the Asia and Pacific Region by Economy (US\$ Billion) Source: Coordinated Portfolio Investment Survey (CPIS), IMF.

\section{Case of Japan:}

- Among the Asia and Pacific economies, Japan has been the largest portfolio investor to the world as well as the largest recipient of global money before, during, and after the global financial crisis. Comparing the pre-crisis and post-crisis periods, Japan's average amount of cross-border portfolio assets (or liabilities) to 
the world has risen by $86 \%$ (or $81 \%$ ). Japan's cross-border portfolio assets and liabilities have remained heavily biased toward the US and the EU before, during, and after the crisis.

- While the US and the EU have remained as Japan's portfolio investment top partners, their collective share in Japan's total cross-border portfolio assets has dropped from $72 \%$ in the pre-crisis period to $66 \%$ in the post-crisis period. Their share in Japan's cross-border foreign portfolio liabilities has also fallen from $80 \%$ to $72 \%$ over the same time span. These trends suggest that Japan has diversified its investment destinations and sources of financing over time, particularly to the Asia and Pacific economies. Comparing the pre-crisis and post-crisis periods, Japan's cross-border portfolio assets have grown toward ASEAN-5 (by 281\%), Australia (by 254\%), Korea (by 212\%), China (by 160\%), and Hong Kong (by 95\%). Similarly, Japan's portfolio investment liabilities against the Asia and Pacific region have grown at impressive rates: $492 \%$ against Korea, 172\% against Hong Kong, and 104\% against Australia.

- As foreign assets have always exceeded foreign liabilities, Japan has remained a net international creditor of cross-border portfolio investment over the period. This is true not only against the US and the EU, but also against almost all the Asia and Pacific economies except for Hong Kong - where Japan's cross-border portfolio liabilities have exceeded its assets. Overall, Japan has functioned as an "investor nation" to the world - namely as a provider of capital to the world.

- In the pre-crisis period, Japan's net cross-border portfolio creditor position has been biggest against the EU (US\$313 billion on average during 2001-2007), followed by the US (US\$274 billion). In contrast, Japan's net assets in the post-crisis period have been largest vis-à-vis the US, with net assets of US\$601 billion on average during 2010-2017. It has been then followed by the EU (US\$457 billion). A switch of Japan's positions between the EU and the US between the pre-crisis and the post-crisis period reflects a slower economic recovery in the EU than in the US as well as the long-lasting impact of the global financial crisis and the European Sovereign Debt Crisis of 2010-2012.

- Vis-à-vis the Asia and Pacific region, Japan's net portfolio assets have remained relatively small over the same time span. Australia has remained as Japan's biggest investment destination economy throughout 2001-2017. Japan's net assets vis-à-vis Australia in the post-crisis period have reached 4.3 times of the pre-crisis level. Meanwhile, Japan's net assets vis-à-vis Korea during 2010-2017 have reached 2.3 times the pre-crisis level. Albeit from a low level, Japan's net portfolio assets of portfolio investment vis-à-vis the ASEAN-5 economies excluding Singapore increases significantly, presumably due to the following reasons: (i) Japan's low interest rate environment driven by a series of monetary easing since 1999 (Shirai 2018); (ii) increased attractiveness of portfolio securities issued by the ASEAN due to high yields and reasonable stock prices based on price to earnings (P/E) ratios; and (iii) deliberate efforts by central banks and governments of these economies to attract capital inflows for boosting foreign reserves and deepening their financial markets.

\section{Case of Australia:}

- As foreign liabilities persistently exceeded foreign assets, Australia has been a net debtor of cross-border portfolio investment to the world. Australia's foreign assets have expanded by about $215 \%$ from the pre-crisis period to the post-crisis period. Its foreign liabilities have risen by about $156 \%$ over the same time span.

- Australia has maintained large exposure to the US and EU with regards to foreign portfolio assets, together accounting for $77 \%$ before the global financial crisis but has declined to $67 \%$ in the post-crisis period as Australia has diversified its investment destinations. As for foreign liabilities, Australia's dependence on the US has risen from $31 \%$ in the pre-crisis period to $33 \%$ in the post-crisis period, but its dependence on the EU has dropped from $36 \%$ to $29 \%$ over the same period.

- The relative position of the Asia and Pacific region in terms of Australia's foreign assets and liabilities has not changed much throughout the period. Namely, the share of its assets in the Asia and Pacific region has risen marginally from $10 \%$ to $11 \%$, while its share of liabilities to the region has fallen slightly from $23 \%$ to $22 \%$.

- Japan has been the main destination of Australia's portfolio investment in the Asia and Pacific region before, during, and after the global financial crisis. Japan has also been the region's main investor to Australia's portfolio liabilities over the same time span. 
- Australia has remained a net debtor of portfolio investment against the EU, the US, and many of the Asia and Pacific economies before, during, and after the global financial crisis. Korea has been an exception since Australia has remained a net creditor of Korea's portfolio investment throughout the three periods.

\section{Case of Singapore:}

- Singapore has remained a net investor of cross-border portfolio investment before, during, and after the global financial crisis. Singapore's foreign assets have grown by $228 \%$ from the pre-crisis period to the post-crisis period. Its foreign liabilities have risen by $202 \%$ over the same time span. Singapore also appears to play an increasingly important role in the Asia and Pacific region as a major investor in the region.

- As for foreign assets, Singapore has increased the share of foreign assets vis-à-vis the US from $23 \%$ before the global financial crisis to $28 \%$ after the crisis. In contrast, the share of foreign asset vis-à-vis the EU has dropped significantly from $30 \%$ to $10 \%$ over the same time span. After the crisis, the US has taken over the EU as Singapore's top destination for portfolio investment. Singapore's role as a financier in the Asia and Pacific region has also grown not only within the ASEAN, but also with China, Hong Kong, and Japan. The share of the foreign assets vis-à-vis China has increased from $2 \%$ before the crisis to $9 \%$ after the crisis. Especially, Singapore's growing direct exposure to securities issued by China is noticeable.

- Regarding foreign liabilities, the US and the EU have remained as major financiers of Singapore's securities. Nonetheless, Singapore's portfolio liabilities against the Asia and Pacific region have grown at an impressive pace between the crisis and post-crisis periods, particularly against Malaysia (20.3 times of the pre-crisis level), Indonesia (5.5 times); Thailand (4.4 times); and Korea (4.0 times).

- As foreign assets constantly exceeded foreign liabilities, Singapore remained a net investor nation against the US, the EU, and the Asia and Pacific region. Its net portfolio assets vis-à-vis the US have risen from US\$26 billion on average in the pre-crisis period to US\$152 billion in the post-crisis period, while its net assets against the EU have fallen from US\$54 billion to US\$22 billion.

- $\quad$ Singapore has maintained net portfolio assets of US\$72 billion on average vis-à-vis China during 2010 2017 (the pre-crisis foreign liabilities data on China is not available). Over the same period, China has been Singapore's third largest destination of portfolio investment (after the US and the EU), while Singapore's portfolio liabilities against China have been relatively small.

\section{Case of Hong Kong:}

- Among the Asia and Pacific economies, Hong Kong has been the second largest portfolio investor to the world after Japan. Cross-border portfolio assets (or liabilities) of Hong Kong to the world have grown by $176 \%$ (or 164\%) between the crisis and the post-crisis periods. The rapid growth of foreign portfolio assets and liabilities of Hong Kong has been comparable to that of Singapore; both economies' assets and liabilities growth rates have exceeded those of Japan. This suggests that international financial centers in Singapore and Hong Kong are rapidly growing over time.

- Hong Kong has maintained a strong financial relationship with China. During 2010-2017, Hong Kong's portfolio assets in the securities issued by China have reached US $\$ 302$ billion on average, exceeding those issued by the EU (US\$170 billion) and the US (US\$104 billion).

- Hong Kong has been a net creditor of cross-border portfolio investment vis-à-vis the EU before, during, and after the crisis. The EU was the most important investment destination for Hong Kong in the pre-crisis period and during the crisis period. Hong Kong's strong attachment to the EU is attributable to the economy's history as a British colony during 1841-1997. After the 2008-2009 global financial crisis, however, Hong Kong's biggest cross-border portfolio investment destination has shifted from the EU to China.

- Hong Kong has been a net debtor of cross-border portfolio investment against the US before and after the crisis but was a net creditor during the crisis due to the capital reversal from the economy to the US. Hong Kong's portfolio assets in the US were never as large as its assets in the EU.

- The ASEAN-5 economies, particularly Singapore, have been a relatively large investor of securities issued by Hong Kong. ASEAN-5's assets in the securities issued by Hong Kong grew from US\$13 billion on average before the crisis to US $\$ 16$ billion during the crisis, and further to US $\$ 32$ billion in the post-crisis period. This may be associated with the interest of the ASEAN-5 economies through deep trade and FDI 
relationships with China and Hong Kong as well as the presence of overseas Chinese in the Southeast Asia region.

- It is worth noting that out of the ASEAN-5's portfolio assets in the securities issued by Hong Kong, Singapore's share has gradually fallen from $94 \%$ in the pre-crisis period, to $85 \%$ during the crisis period, and further to $78 \%$ in the post-crisis period. This decline is mainly due to the rapid increase of Malaysia's and Thailand's portfolio assets in the securities issued by Hong Kong.

- Hong Kong appears to be playing a role as a regional financial center. It serves not only as a gateway of portfolio investment from the advanced economies to China but also for investment from the ASEAN-5 and investment to China.

\section{Case of China:}

- China has been a net debtor of cross-border portfolio investment to the world. China's cross-border portfolio assets have recorded US $\$ 379$ billion on average in the post-crisis period while its liabilities have amounted to US\$762 billion. Comparing the pre-crisis and post-crisis periods, China’s portfolio liabilities to the world have grown by $431 \%$. The impressive growth rate not only indicates rapid growth of the securities markets but also shows that capital account liberalization has progressed over time.

- There are strong interests by other Asia and Pacific economies to invest in securities issued by China. Foreign portfolio liabilities of China vis-à-vis Hong Kong have risen substantially by $472 \%$, from US $\$ 53$ billion in the pre-crisis period to US\$302 billion in the post-crisis period. Albeit from the low level, China's foreign portfolio liabilities against Australia have grown by 2,159\% over the same period (from about US $\$ 0.3$ billion to more than US\$6 billion), while its liabilities against the ASEAN-5 have grown by $1,147 \%$ (from almost US\$7 billion to US\$82 billion).

- China's cross-border portfolio liabilities against the EU and the US have also grown substantially between the pre-crisis and the post-crisis periods: by $282 \%$ and $241 \%$, respectively. This indicates the rising interest by the EU and the US with regards to investing in securities issued by China.

\section{Cross-Border Portfolio Assets and Liabilities Classified by Types of Instruments in the Asia and Pacific Region}

Table 5 decomposes data on cross-border portfolio investment asset and liabilities by types of investment instruments: (i) equity; (ii) long-term debt securities; and (iii) short-term debt securities.

Table 5. Average Cross-Border Portfolio Investment Assets and Liabilities in Asia and Pacific Economies by Instrument (Unit: US\$ Million)

\begin{tabular}{lcccc}
\hline \multicolumn{4}{c}{ Assets } \\
\hline & Equity & Long-term Debt Securities & $\begin{array}{c}\text { Short-term Debt } \\
\text { Securities }\end{array}$ & $\begin{array}{c}\text { Total Portfolio } \\
\text { Investment }\end{array}$ \\
\hline $2001-2007$ & 880,135 & $1,882,461$ & 110,034 & $2,872,632$ \\
$2008-2009$ & $1,356,317$ & $2,665,775$ & 152,884 & $4,174,976$ \\
$2010-2017$ & $3,034,176$ & $3,574,593$ & 318,594 & $6,927,363$ \\
\hline
\end{tabular}

\begin{tabular}{cccccc}
\hline \multicolumn{6}{c}{ Liabilities } \\
\hline & Equity & $\begin{array}{c}\text { Long-term Debt } \\
\text { Securities }\end{array}$ & $\begin{array}{c}\text { Short-term Debt } \\
\text { Securities }\end{array}$ & $\begin{array}{c}\text { Statistical } \\
\text { Discrepancy }\end{array}$ & $\begin{array}{c}\text { Total Portfolio } \\
\text { Investment }\end{array}$ \\
\hline $2001-2007$ & $1,421,451$ & 530,855 & 140,926 & $-7,540$ & $2,085,692$ \\
$2008-2009$ & $1,754,025$ & 841,765 & 317,700 & 33,983 & $2,947,472$ \\
$2010-2017$ & $3,086,750$ & $1,513,815$ & 574,594 & $-46,907$ & $5,128,253$ \\
\hline
\end{tabular}

Source: Coordinated Portfolio Investment Survey (CPIS), IMF.

With regards to cross-border portfolio assets held by the Asia and Pacific region, the following four features are observed.

First, cross-border portfolio assets held by the Asia and Pacific region to the world have remained dominated by debt securities. This mainly reflects that Japan has persistently preferred holding a greater amount of cross-border portfolio assets in the form of long-term debt securities. Japanese debt securities investors have been heavily skewed toward advanced economies that have large, deep, mature debt securities markets. Japan's debt securities assets in the US and the EU have been disproportionately large as compared to its assets in the 
Asia and Pacific region in the post-crisis period. Among the region, Australia has become Japan's preferred investment destination in terms of long-term debt securities over the same period mainly because Australia has a relatively deep, matured market with high-rated sovereign bonds.

Second, the amount of both equity and debt securities assets have increased throughout 2001-2017, but equity securities assets have grown faster than debt securities assets. The share of debt securities to total foreign portfolio assets held by the Asia and Pacific region has gradually declined from $69 \%$ in the pre-crisis period to $56 \%$ in the post-crisis period. Instead, the share of equity to total portfolio assets held by the Asia and Pacific region rose from $31 \%$ in the pre-crisis period to $44 \%$ in the post-crisis period. This is partly because Japan's foreign equity holdings have rapidly increased since 2014 because of a search for higher returns and due to the Japanese government's pension fund reform. Also, Australian investors tend to take more risks than Japanese investors, as evidenced by their tendency to invest more actively in equity than in debt securities. This may reflect that major Australian investors are superannuation funds (mostly based on defined contribution schemes) and other funds. However, the global financial crisis substantially reduced Australia's appetite for investing in riskier assets.

Third, Hong Kong has maintained its foreign assets mainly in the form of equity. In the post-crisis period, equity constituted $62 \%$ of Hong Kong's portfolio assets vis-à-vis the world. The relationship between China and Hong Kong has strengthened over time, and Hong Kong has remained the largest investor in equity issued by China. Given that China has the largest debt securities market among the emerging Asian economies, further capital account liberalization is likely to attract greater investment from abroad and from the region. The inclusion of China's yuan-denominated Chinese stocks (the so-called 'A' shares) by the MSCI into its key Emerging Markets and World from June 2018 has boosted equity investment to China. Global fund managers have issued various MSCI-based fund indexes by selecting prospective stocks in China.

Fourth, Singapore has become more aggressive in investing in the emerging markets. For example, Singapore's net equity assets have risen by around $400 \%$ after the crisis. Singapore's interest in equity issued by China has grown rapidly although its holding of equity assets in the US has remained larger. In addition to the growing role of Singapore in the Asia and Pacific region, it should be mentioned that other ASEAN economies have also increased their linkages with other Asia and Pacific economies over time. For example, the Philippines has increased its portfolio investment in Indonesia, where Indonesia's share of the Pilipino total portfolio assets rose from about $0 \%$ in the pre-crisis period to $17 \%$ in the post-crisis period. Meanwhile, Thailand has increased its portfolio assets to Korea from $3 \%$ of Thai total foreign portfolio assets in the pre-crisis period to $11 \%$ in the post-crisis period.

Next, portfolio investment liabilities of the Asia and Pacific region throughout 2001-2017 have the following features:

First, portfolio investment liabilities of the Asia and Pacific region toward the world have been dominated by equity. Japanese equity investment liabilities toward the US have remained large, accounting for more than half of Japan's cross-border equity investment liabilities. There is a rapid increase of Japanese stock prices after the launch of Abenomics from late 2012 and the subsequent unconventional monetary easing adopted by the Bank of Japan since April 2013 - including the massive purchase of the Japanese Government Bonds and ETF purchases (largely indexed to Nikkei 225 and TOPIX).

Second, the dominance of equity in portfolio investment liabilities in the region may also reflect the early stages of bond market development in many emerging Asian economies. This is partly because some emerging economies have begun to promote debt securities markets relatively late. Indonesia, for example, introduced the government debt securities more formally to foster their market in 2002 by issuing a law on government debt securities. With this law, the Indonesian government can regularly issue debt securities with adequate issuance size. Prior to 2002, the Indonesian government issued debt securities only irregularly.

Third, China has faced rapid growth in portfolio investment liabilities and has increasingly attracted capital from other economies, as it continues to open up its financial markets. China's portfolio investment liabilities have been dominated by equity liabilities, although debt securities are gradually catching up. During 2010-2017, China's equity liabilities stood at US\$ 545 billion on average billion while its debt securities liabilities were at US\$ 216 billion. Both China's equity liabilities and debt securities have surpassed those of Hong Kong during and after the global financial crisis period. With regards to short-term debt securities, China has relatively heavily invested in short-term debt securities issued by Hong Kong.

Fourth, it should be noted that the amount of debt securities investment liabilities has grown faster than the amount of equity investment liabilities after the crisis even though equity remains a dominant form of 
cross-border liabilities. Namely, the shares of equity in portfolio investment liabilities have dropped from $68 \%$ in the pre-crisis period to $60 \%$ in the post-crisis period; and the shares of debt securities have risen from $32 \%$ to $40 \%$ over the same period. This is a result opposite to the case of portfolio investment assets. A relative shift of the portfolio investment liabilities from equity to debt securities may reflect that equity prices in the Asia and Pacific region have become more expensive or overvalued in many economies, as demonstrated by rising price to earnings ratios and rising real yields.

As a supplement to the main analysis above, this paper also uses random effect pooled data analysis to examine variables that may affect cross-border portfolio investment to the Asia and Pacific region (see the Supplemental Analysis section). In general, long-term debt securities investment to Asia and the Pacific economies are affected the respective economy's exchange rate and yield of government bond, and currency in circulation in the investors' home economies. Meanwhile, equity investment to the Asia and Pacific economies are affected by the respective economy's exchange rate and price to earnings ratio.

\section{Conclusion}

This paper has examined movements of cross-border portfolio investment assets and liabilities in the Asia and Pacific region before, during, and after the global financial crisis. There have been significant flows of cross-border portfolio investment to and from the region over time. Both equity and debt securities investment from the world to the region have increased throughout 2001-2017, and so have equity and debt securities investment from the region to the world.

With regards to the regions' cross-border assets, debt securities have consistently exceeded equity. This mostly reflects Japan's strong bias toward debt securities issued by the US, the EU, and Australia. Excluding Japan, many economies in the region invested more heavily in cross-border equity than debt securities. Meanwhile, the region's cross-border portfolio liabilities have been largely in the form of equity. Major investors in equity issued by the region have been from the US and the EU. One exception is China, where major equity investors have been from Hong Kong. Foreign investors' preference for equity over debt securities may reflect that bond markets have remained at the early stage of development in the region's emerging economies.

Albeit from a low level, the intra-regional financial integration has been growing at the center of China, which has attracted equity investment from Hong Kong and Singapore. Indonesia has increased its investment in equity issued by China. Meanwhile, China has relatively heavily invested in short-term debt securities issued by Hong Kong. Within the ASEAN-5, Malaysia has increased equity investment to Singapore; Singapore has increased equity investment in Indonesia, Malaysia, and Thailand; while Malaysia has increased investment in Singaporean equity. Singapore has also increasingly invested in debt securities issued by Indonesia and Malaysia. Thus, Singapore has not only increased exposure to China but also other ASEAN economies, suggesting that Singapore has increased its presence as a regional financial center.

\section{References}

Asian Development Bank. (2018). Asia Bond Monitor March 2018. Manila: Asian Development Bank.

Asian Development Bank. (2018). Asian Economic Integration Report 2018. Manila: Asian Development Bank. https://doi.org/10.22617/TCS189598-2

Baltagi, B. (2013). Econometric Analysis of Panel Data, $5^{\text {th }}$ ed. New Jersey: John Wiley \& Sons, Inc.

BlackRock (2017). Addressing Market Liquidity: A Perspective on Asia's Bond Markets. New York, NY: BlackRock.

Caporale, G. M., Luis, G. A., \& Kefei, Y. (2019). Stock Market Linkages Between the ASEAN Countries, China, and the US: a Fractional Cointegration Approach. CESifo Working Paper, No. 7357. Munich: Munich Society for the Promotion of Economic Research - CESifo GmbH.

Cavallo, M., Marco, D. N., W. Scott, F., Jamie, G., Benjamin, A. M., \& Carlo, R. (2018). Fiscal Implication of the Federal Reserve's Balance Sheet Normalization. Federal Reserve Bank of New York Staff Report, No. 833. New York, NY: Federal Reserve Bank of New York.

Hattari, R., \& Ramkishen, S. R. (2011). How Different are FDI and FPI Flows: Distance and Capital Market Integration. Journal of Economic Integration, 26(3). Seoul: Center for Economic Integration, Sejong University.

Masaru, Y., \& Sayuri, S. (2001). Designing a Financial Market Structure in Post-Crisis Asia - How to Develop Corporate Bond Markets. ADB Institute Working Paper, No.15. Tokyo: ADB Institute. 
OECD (2017). OECD Equity Markets Review: ASIA 2017. Paris: OECD.

Sayuri, S. (2018). Mission Incomplete: Reflating Japan's Economy, $2^{\text {nd }}$ ed. Tokyo: ADB Institute.

Shu, C., Dong, H., Honglin, W., \& Jinyue, D. (2015). The Influence of Chinese and US Financial Markets on Asia-Pacific. BIS Paper, No. 82. Basel: Bank for International Settlements.

Shu, C., Dong, H., Honglin, W., \& Jinyue, D. (2016). Regional Pull vs Global Push Factors: China and US Influence on Asia-Pacific Financial Markets. BIS Paper, No. 579. Basel: Bank for International Settlements.

Z/Yen (2019). Global Financial Center Index 25, March 2019. London: Z/Yen. 


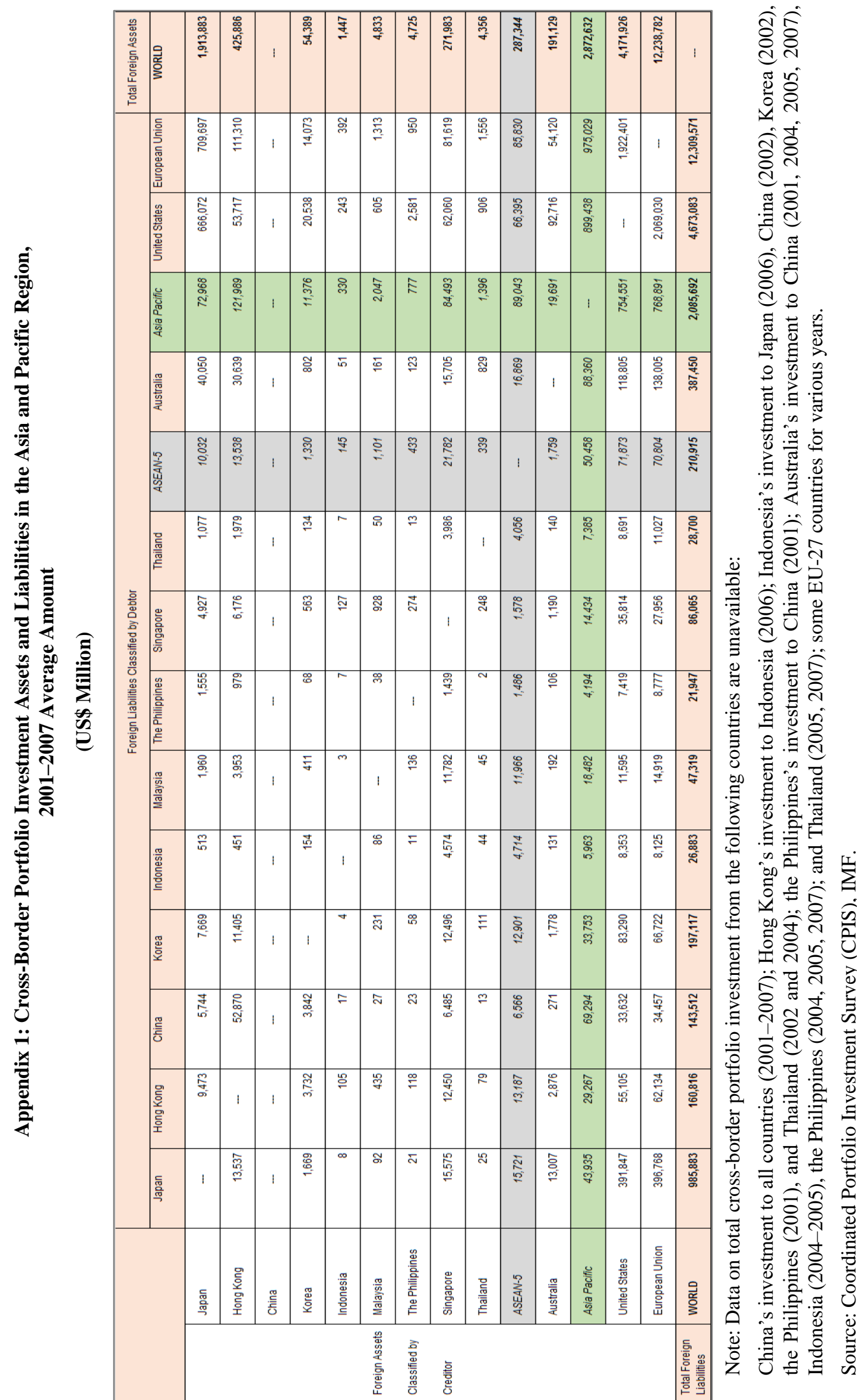




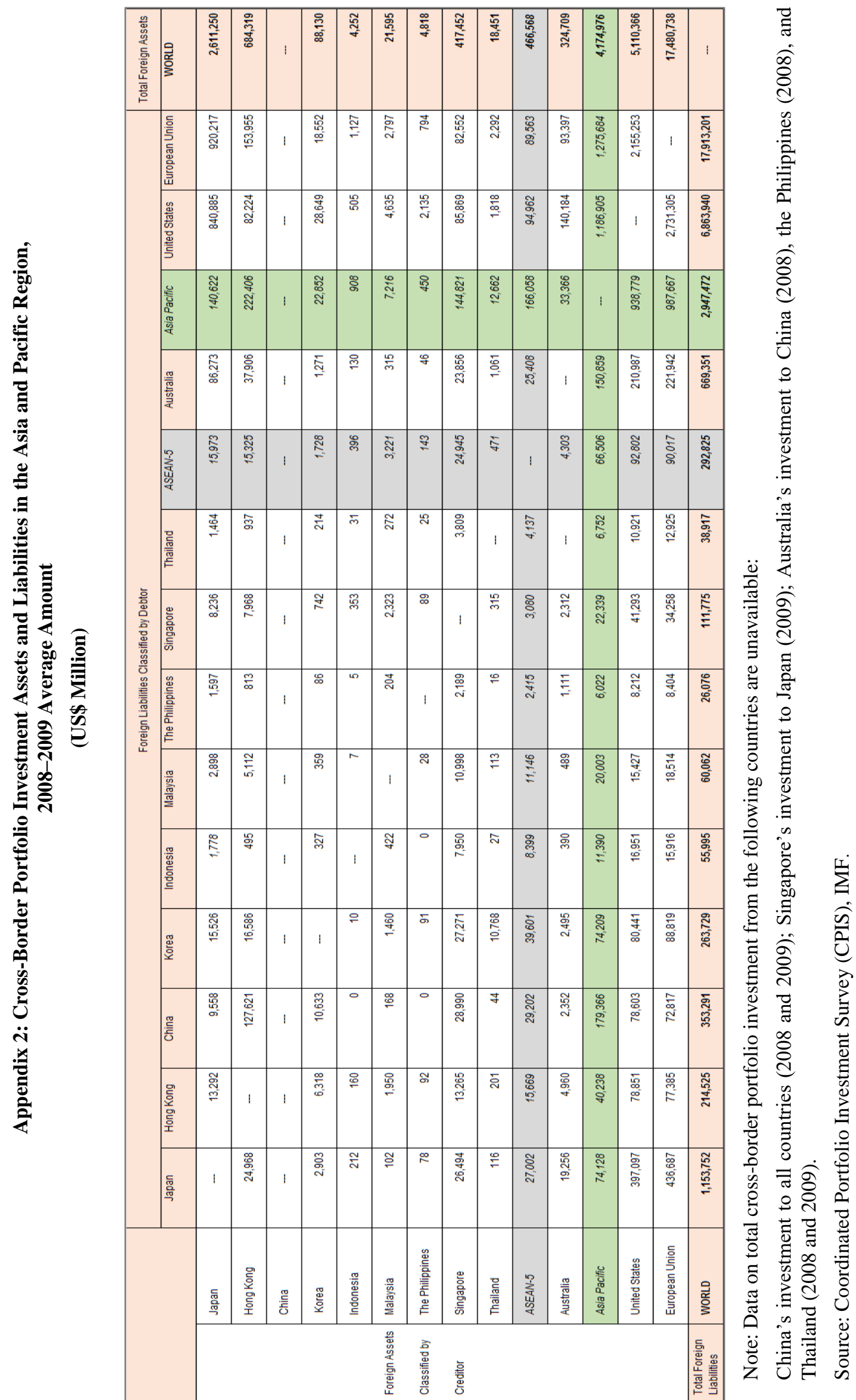




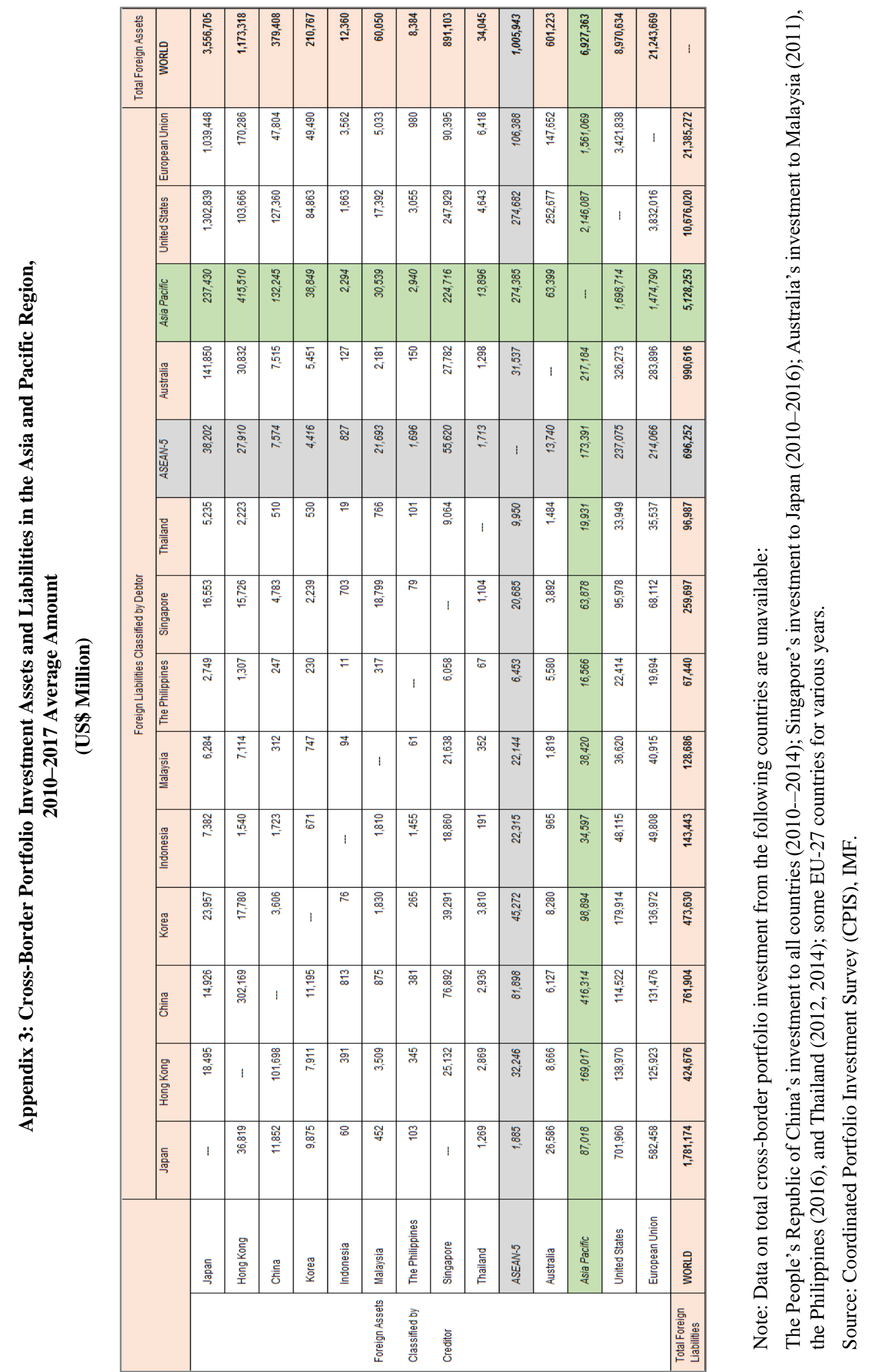




\section{SUPPLEMENTAL ANALYSIS}

\section{Variables Affecting Cross-border Portfolio to or from the Asia and Pacific Region}

This study uses random effect pooled data model to examine variables that may affect cross-border portfolio investment to the Asia and Pacific region. The random effect model is selected due to the presence of cross-section heteroskedasticity in the pooled data and the result of the Hausman test that suggested that the random effect might be more suitable than the fixed effect model. Results of parameter estimates from the models are displayed in Table S1 for long-term debt securities and Table S2 for equity.

Based on the F-test, the random effect model fits to analyze long-term debt investment to the Asia and Pacific economies, except for the case of Malaysia (Table S1). The dependent variable of the model is the outstanding cross-border long-term debt securities investment to each of the Asia and Pacific economies, while the independent variables are the respective economy's exchange rate against USD (i.e., its currency unit per USD), the yield of its government bond (i.e., the 10-year yield), and the amount of currency in circulation in the economies of origin of the investment ("partner economies"). As the model does not fit well for Malaysia, the paper excluded this economy in the following discussion related to bonds.

Exchange rate is a significant variable for Hong Kong, China, Indonesia, Singapore, Thailand, and Australia; but not significant for Japan, Korea, and the Philippines. A negative (positive) sign of the exchange rate parameter implies that portfolio investment to the respective economy tend to fall (increase) when its currency depreciates. In other words, long-term debt securities investment to Hong Kong, Indonesia, and Australia tend to increase whenever their currencies depreciate; while such investment to China, Singapore, and Thailand tend to fall when these countries' currencies depreciate.

Government bond yield is a significant variable for most of the Asia and Pacific economies (except for China and Singapore). When this variable is statistically significant, the variable's parameter is negative; indicating that long-term debt securities investment tends to fall whenever the bond yield increases (or the bond price declines). Hence, when the bond yield increases, foreign investors tend to reduce their cross-border bond assets to prevent the risk of an evaluation loss - rather than increasing their holdings of such assets by taking advantage of a declined bond price. This finding seems to be counterintuitive to the common belief that bond investors seek for a higher yield in the environment of an excessively-low global interest rate environment. This finding may reflect the importance of a declined market value of the existing accumulated bond assets for incumbent foreign investors in the face of an increase in the yield, which may prompt them to sell these bonds now and purchase such bonds later again when they see that the bond prices are bottomed out.

Currency in circulation in partner economies is a statistically-significant variable for most of the Asia and Pacific economies (except for China) with a negative sign. Nonetheless, the parameter value of this variable is very small, implying that the impact of this variable on long-term debt investment is rather marginal (if not negligible). The negative sign of the variable means that long-term debt securities investment to the Asia and Pacific region tend to decline when the currency in circulation in partner countries increase. Intuitively, the higher amount of currency in circulation may indicate households in the partner economies increase demand for cash rather than placing their money with banks and other financial institutions. This may have reduced source of funding for their cross-border investment.

Regarding cross-border equity investment to the Asia and Pacific economies, the F-test shows that the random effect model fits well (Table S2), except for the case of Singapore. The dependent variable is the outstanding cross-border equity investment to the Asia and Pacific economies, while the independent variables are the respective economy's exchange rate against USD and price to earnings $(\mathrm{P} / \mathrm{E})$ ratio. Currency in circulation in partner economies is not included in the final model as this variable is not significant for the Asia and Pacific economies. This paper excludes Singapore in the following discussion on equity.

Exchange rate is a significant variable for most of the Asia and Pacific economies, except for Indonesia. This study indicates that equity investment to Japan, Hong Kong, and Australia tend to increase when the currencies of these countries depreciate; while equity investment to China, Korea, Malaysia, Thailand, and the Philippines tend to fall when these countries' currencies depreciate.

The P/E ratio is a significant variable for Japan, Hong Kong, Korea, Indonesia, and Thailand; but not significant for China, Malaysia, the Philippines, and Australia. The sign for this variable's parameter is positive for Korea, Indonesia, and Thailand; while negative for Japan and Hong Kong. A positive sign of the P/E ratio parameter indicates that foreign investors tend to buy more equity when the P/E ratio increases. In this case, although higher P/E means that stocks in the respective countries have become more expensive, foreign investors expect that the price increase will continue in the next period thus improving their investment values. A negative sign of $\mathrm{P} / \mathrm{E}$ ratio parameter implies that foreign investors tend to reduce their equity holdings when the $\mathrm{P} / \mathrm{E}$ ratio increases. Foreign investors may see stocks in Korea, Indonesia, and Thailand are largely still undervalued and have more potential upsides than stocks in Japan and Hong Kong. 
Table S1. Variables Affecting Cross-Border Long-Term Debt Securities Investment to the Asia and Pacific

Economies (Pooled data parameter estimates; parameter's t-statistics probability in the respective bracket)

\begin{tabular}{|c|c|c|c|c|c|}
\hline & Japan & Hong Kong & China & Korea & Indonesia \\
\hline Constant & $\begin{array}{r}42000.33^{*} \\
(0.0080)\end{array}$ & $\begin{array}{r}-180529.3 * * \\
(0.0613)\end{array}$ & $\begin{array}{r}39110.63 * \\
(0.0071)\end{array}$ & $\begin{array}{r}22295.64^{*} \\
(0.0002)\end{array}$ & $\begin{array}{r}-2448.093 \\
(0.5464)\end{array}$ \\
\hline Exchange rate / USD & $\begin{array}{r}-56.40061 \\
(0.4548) \\
\end{array}$ & $\begin{array}{r}24121.10^{* * *} \\
(0.0527) \\
\end{array}$ & $\begin{array}{r}-4479.132 * \\
(0.0055) \\
\end{array}$ & $\begin{array}{r}-4.594434 \\
(0.3159) \\
\end{array}$ & $\begin{array}{r}1.432201 * \\
(0.0000) \\
\end{array}$ \\
\hline 10Y gov. bond yield & $\begin{array}{r}-15806.04 * \\
(0.0000)\end{array}$ & $\begin{array}{r}-968.3622 * \\
(0.0000)\end{array}$ & $\begin{array}{r}-1450.952 \\
(0.3781)\end{array}$ & $\begin{array}{r}-2051.250^{*} \\
(0.0000)\end{array}$ & $\begin{array}{r}-872.6365^{*} \\
(0.0000)\end{array}$ \\
\hline Currency in circulation in partner economies & $\begin{array}{r}-0.010493^{*} \\
(0.0168) \\
\end{array}$ & $\begin{array}{r}-0.001591 * * \\
(0.0542) \\
\end{array}$ & $\begin{array}{r}0.002737 \\
(0.4782) \\
\end{array}$ & $\begin{array}{r}-0.004898^{*} \\
(0.0113)\end{array}$ & $\begin{array}{r}-0.006139^{*} \\
(0.0058)\end{array}$ \\
\hline \multicolumn{6}{|l|}{ Random effect (cross) } \\
\hline Japan & --- & -1696.725 & -2645.513 & 2627.080 & -1600.465 \\
\hline _Hong Kong & -7142.293 & --- & 23504.63 & 2336.118 & -3116.743 \\
\hline China & -28894.51 & 13265.07 & --- & -9554.492 & -7588.192 \\
\hline _Korea & -16933.16 & -2723.181 & -2131.787 & --- & -4004.529 \\
\hline Indonesia & -17646.37 & -3515.578 & -5117.750 & -7053.349 & --- \\
\hline _Malaysia & -18626.59 & -3613.634 & -3633.511 & -7140.081 & -3858.426 \\
\hline _Singapore & -7046.267 & 1303.389 & 2937.214 & 2779.771 & 1614.771 \\
\hline Thailand & -9285.526 & -2205.679 & -4968.672 & -1799.614 & 987.0257 \\
\hline _Philippines & -5724.648 & -1946.701 & -9320.225 & -1456.714 & 5165.534 \\
\hline Australia & -19053.50 & -2630.607 & -2831.297 & -6883.880 & -4638.099 \\
\hline European Union & 100821.4 & 5402.342 & 5958.402 & 17221.02 & 10793.08 \\
\hline United States & 29531.48 & -1638.697 & -1751.488 & 8924.139 & 6246.042 \\
\hline \multicolumn{6}{|l|}{ Weighted Statistics } \\
\hline R-squared & 0.195460 & 0.145090 & 0.076050 & 0.176206 & 0.323592 \\
\hline Adjusted R-squared & 0.178462 & 0.128754 & 0.052154 & 0.160158 & 0.308102 \\
\hline F-statistic & $11.49944 *$ & $8.881695 *$ & $3.182620 *$ & $10.97996^{*}$ & $20.89002^{*}$ \\
\hline Prob(F-statistic) & 0.000001 & 0.000018 & 0.026572 & 0.000001 & 0.000000 \\
\hline
\end{tabular}

\begin{tabular}{|c|c|c|c|c|c|}
\hline & Malaysia & Singapore & Thailand & Philippines & Australia \\
\hline Constant & $\begin{array}{r}104.5110 \\
(0.9776) \\
\end{array}$ & $\begin{array}{r}16088.89^{*} \\
(0.0000) \\
\end{array}$ & $\begin{array}{r}6270.154^{*} \\
(0.0000) \\
\end{array}$ & $\begin{array}{r}3166.505^{*} \\
(0.0451)\end{array}$ & $\begin{array}{r}21876.45 \\
(0.2504)\end{array}$ \\
\hline Exchange rate / USD & $\begin{array}{r}571.4447 \\
(0.3896) \\
\end{array}$ & $\begin{array}{r}-8506.184^{*} \\
(0.0000) \\
\end{array}$ & $\begin{array}{r}-77.74978^{*} \\
(0.0254) \\
\end{array}$ & $\begin{array}{r}12.18678 \\
(0.7161) \\
\end{array}$ & $\begin{array}{r}68240.42^{*} \\
(0.0000)\end{array}$ \\
\hline 10Y gov. bond yield & $\begin{array}{r}487.6520 \\
(0.5925)\end{array}$ & $\begin{array}{r}5.267747 \\
(0.9914) \\
\end{array}$ & $\begin{array}{r}-621.0090 * \\
(0.0000) \\
\end{array}$ & $\begin{array}{r}-231.1196^{*} \\
(0.0000)\end{array}$ & $\begin{array}{r}-8915.685^{*} \\
(0.0000) \\
\end{array}$ \\
\hline Currency in circulation in partner countries & $\begin{array}{r}-0.001066 \\
(0.4046) \\
\end{array}$ & $\begin{array}{r}-0.001859^{*} \\
(0.0144) \\
\end{array}$ & $\begin{array}{r}-0.000991^{* *} \\
(0.0698) \\
\end{array}$ & $\begin{array}{r}-0.002815^{*} \\
(0.0010) \\
\end{array}$ & $\begin{array}{r}-0.026655^{*} \\
(0.0008) \\
\end{array}$ \\
\hline \multicolumn{6}{|l|}{ Random effect (cross) } \\
\hline Japan & -602.1943 & 1483.832 & 550.3392 & -33.89303 & 41650.88 \\
\hline _Hong Kong & -410.7107 & 874.3819 & -462.1122 & -701.5110 & -7540.192 \\
\hline China & -3930.406 & -1957.553 & -1415.680 & -2425.488 & -42630.18 \\
\hline Korea & -3537.409 & -2663.953 & -894.4900 & -1724.895 & -32215.99 \\
\hline Indonesia & -3464.358 & -2599.522 & -1113.291 & -1110.376 & -27173.53 \\
\hline _Malaysia & --- & -370.8579 & -836.4412 & -1732.518 & -33743.56 \\
\hline Singapore & 3385.242 & --- & 737.9245 & -375.3819 & -22624.90 \\
\hline _Thailand & -2792.681 & -1732.782 & --- & 486.5933 & -11982.23 \\
\hline _Philippines & -2013.152 & -1094.391 & 221.0413 & --- & -504.2847 \\
\hline Australia & -3310.697 & -2755.829 & -1024.618 & -1121.442 & --- \\
\hline _European Union & 12092.04 & 7475.542 & 3427.341 & 5508.189 & 86333.24 \\
\hline _United States & 4584.325 & 3341.133 & 809.9866 & 3230.723 & 50430.74 \\
\hline \multicolumn{6}{|l|}{ Weighted Statistics } \\
\hline R-squared & 0.015614 & 0.237610 & 0.187177 & 0.251512 & 0.314807 \\
\hline Adjusted R-squared & -0.009844 & 0.223316 & 0.170701 & 0.236931 & 0.302118 \\
\hline F-statistic & 0.613320 & $16.62216^{*}$ & $11.36046^{*}$ & 17.24940* & $24.80986^{*}$ \\
\hline Prob(F-statistic) & 0.607705 & 0.000000 & 0.000001 & 0.000000 & 0.000000 \\
\hline
\end{tabular}

$*=$ significant at $5 \%$ significance level; $* *=$ significant at $10 \%$ significance level

Source: Authors' calculations 
Table S2. Variables Affecting Cross-Border Equity Investment to the Asia and Pacific Economies (Pooled data parameter estimates; parameter's t-statistics probability in the respective bracket)

\begin{tabular}{|c|c|c|c|c|c|}
\hline & Japan & Hong Kong & China & Korea & Indonesia \\
\hline Constant & $\begin{array}{r}24508.08 \\
(0.7159) \\
\end{array}$ & $\begin{array}{r}-1191761.0 * * \\
(0.0550) \\
\end{array}$ & $\begin{array}{r}202926.0^{*} \\
(0.0000) \\
\end{array}$ & $\begin{array}{r}42686.10^{* * *} \\
(0.0784) \\
\end{array}$ & $\begin{array}{r}-4121.244 \\
(0.1724) \\
\end{array}$ \\
\hline Exchange rate / USD & $\begin{array}{r}869.5707 * \\
(0.0301) \\
\end{array}$ & $\begin{array}{r}160703.8^{*} \\
(0.0458) \\
\end{array}$ & $\begin{array}{r}-25354.03^{*} \\
(0.0000) \\
\end{array}$ & $\begin{array}{r}-34.35870^{* * *} \\
(0.0539) \\
\end{array}$ & $\begin{array}{r}-0.049306 \\
(0.8665) \\
\end{array}$ \\
\hline P/E Ratio & $\begin{array}{r}-1689.403^{*} \\
(0.0000) \\
\end{array}$ & $\begin{array}{r}-2409.337^{*} \\
(0.0001) \\
\end{array}$ & $\begin{array}{r}210.9559 \\
(0.4841) \\
\end{array}$ & $\begin{array}{r}1153.825^{*} \\
(0.0129) \\
\end{array}$ & $\begin{array}{r}451.6810^{*} \\
(0.0000) \\
\end{array}$ \\
\hline \multicolumn{6}{|l|}{ Random effect (cross) } \\
\hline Japan & --- & -12993.62 & -17792.73 & -14100.82 & -1667.267 \\
\hline _Hong Kong & -65475.39 & --- & 88359.22 & -17610.80 & -2930.399 \\
\hline China & -78735.08 & 38120.52 & --- & -16764.50 & -4692.124 \\
\hline _Korea & -66917.89 & -19611.34 & -19529.88 & --- & -2879.658 \\
\hline Indonesia & -70237.35 & -24079.60 & -31336.30 & -20031.44 & --- \\
\hline _Malaysia & -71243.71 & -22599.97 & -25964.21 & -19143.10 & -2634.641 \\
\hline _Singapore & -53770.61 & -13740.59 & 6901.743 & -5991.489 & 1266.761 \\
\hline _Thailand & -71307.36 & -23888.91 & -26142.77 & -19466.38 & -3106.720 \\
\hline Philippines & -86021.40 & -25787.12 & -41437.61 & -20790.36 & -4609.552 \\
\hline Australia & -56659.56 & -18790.32 & -24350.86 & -16352.90 & -3107.192 \\
\hline European Union & 223711.2 & 55357.55 & 46750.26 & 56369.87 & 10076.68 \\
\hline _United States & 396657.2 & 68013.40 & 44543.13 & 93881.92 & 14284.11 \\
\hline \multicolumn{6}{|l|}{ Weighted Statistics } \\
\hline R-squared & 0.112470 & 0.089086 & 0.307097 & 0.064153 & 0.191434 \\
\hline Adjusted R-squared & 0.100792 & 0.078045 & 0.298748 & 0.051245 & 0.181068 \\
\hline F-statistic & 9.630878* & $8.068366^{*}$ & $36.78584 *$ & $4.969932 *$ & $18.46710^{*}$ \\
\hline Prob(F-statistic) & 0.000115 & 0.000454 & 0.000000 & 0.008172 & 0.000000 \\
\hline
\end{tabular}

\begin{tabular}{|c|c|c|c|c|c|}
\hline & Malaysia & Singapore & Thailand & Philippines & Australia \\
\hline Constant & $\begin{array}{r}6673.543 \\
(0.0739)\end{array}$ & $\begin{array}{r}10183.68 \\
(0.6518)\end{array}$ & $\begin{array}{r}11662.64 * \\
(0.0352)\end{array}$ & $\begin{array}{r}8635.550 * \\
(0.0005)\end{array}$ & $\begin{array}{r}-19837.08 \\
(0.2614)\end{array}$ \\
\hline Exchange rate / USD & $\begin{array}{r}-1505.539 * \\
(0.0313)\end{array}$ & $\begin{array}{r}-3960.885 \\
(0.7905)\end{array}$ & $\begin{array}{r}-352.9508^{*} \\
(0.0009)\end{array}$ & $\begin{array}{r}-144.9471 * \\
(0.0020)\end{array}$ & $\begin{array}{r}44457.46^{*} \\
(0.0000)\end{array}$ \\
\hline P/E Ratio & $\begin{array}{r}136.7816 \\
(0.3773)\end{array}$ & $\begin{array}{r}628.0313 \\
(0.2849)\end{array}$ & $\begin{array}{r}338.2592 * \\
(0.0129)\end{array}$ & $\begin{array}{r}-3.348178 \\
(0.2850)\end{array}$ & $\begin{array}{r}194.8373 \\
(0.5905)\end{array}$ \\
\hline \multicolumn{6}{|l|}{ Random effect (cross) } \\
\hline Japan & -2240.468 & -5328.286 & -2658.363 & -1137.494 & -2914.976 \\
\hline _Hong Kong & -2491.852 & -5852.920 & -2667.448 & -1206.401 & -17190.81 \\
\hline _China & -2182.608 & -10103.43 & -4239.248 & -1072.153 & -12559.21 \\
\hline Korea & -3135.552 & -11187.64 & -3641.378 & -1414.315 & -17792.77 \\
\hline Indonesia & -3421.815 & -12066.60 & -4256.814 & -1833.974 & -21008.66 \\
\hline Malaysia & --- & -2175.594 & -3641.551 & -1430.208 & -18765.94 \\
\hline _Singapore & 3010.422 & --- & 44.12480 & -153.4398 & -12269.74 \\
\hline Thailand & -3308.519 & -11460.13 & --- & -1468.294 & -18803.25 \\
\hline _Philippines & -3439.856 & -11992.36 & -3952.594 & --- & -21418.07 \\
\hline Australia & -2856.238 & -9775.355 & -2729.017 & -1009.582 & --- \\
\hline European Union & 8682.263 & 24359.77 & 13250.26 & 3501.531 & 51659.90 \\
\hline United States & 11384.22 & 55582.53 & 14492.03 & 7224.330 & 91063.52 \\
\hline \multicolumn{6}{|l|}{ Weighted Statistics } \\
\hline R-squared & 0.031234 & 0.012542 & 0.170395 & 0.077995 & 0.111024 \\
\hline Adjusted R-squared & 0.018814 & -0.007407 & 0.160089 & 0.065943 & 0.099553 \\
\hline F-statistic & $2.514789 * *$ & 0.628709 & $16.53411 *$ & $6.471395^{*}$ & $9.678962 *$ \\
\hline Prob(F-statistic) & 0.084155 & 0.535396 & 0.000000 & 0.002005 & 0.000109 \\
\hline
\end{tabular}

$*=$ significant at $5 \%$ significance level; $* *=$ significant at $10 \%$ significance level

Source: Authors' calculations

\section{Copyrights}

Copyright for this article is retained by the author(s), with first publication rights granted to the journal.

This is an open-access article distributed under the terms and conditions of the Creative Commons Attribution license (http://creativecommons.org/licenses/by/4.0/). 